\title{
Glycogen and protein profiles of Clinostomum tilapiae Ukoli, 1966 (Digenea: Clinostomidae) and putative species Clinostomum Morphotype1 in a tropical river (Anambra River Basin, Otuocha, Nigeria)
}

\section{Paul Chinedu Echi}

Department of Zoology and Environmental Biology, Michael Okpara University of Agriculture. Umudike. Nigeria. Email: paul_echi@yahoo.com.

\begin{abstract}
There has been little attention to the glycogen and protein profiles of Clinostomum tilapiae Ukoli, 1966 (Digenea: Clinostomidae) and recently studied Clinostomum Morphotype1 as well as the epidemiological status of the later. The protein content of the cyst membrane $10.10 \pm 0.90 \mathrm{~g} / \mathrm{dL}$ and host muscle tissue $11.9 \pm 0.80 \mathrm{~g} / \mathrm{dL}$ are higher than the protein content of Clinostomum Morphotype1 tissue $7.9 \pm 0.40 \mathrm{~g} / \mathrm{dL}$. Conversely, the host muscle tissue glycogen content $8.25 \pm 1.07 \mathrm{mg} / \mathrm{kg}$ is slightly lower than both the cyst tissue $9.20 \pm 0.54 \mathrm{mg} / \mathrm{kg}$ and Morphotype 1 $9.06 \pm 0.79 \mathrm{mg} / \mathrm{kg}$, respectively. However, the glycogen content of Clinostomum tilapiae $13.10 \pm 0.92 \mathrm{mg} / \mathrm{kg}$ is higher than both host muscle tissue glycogen content $8.25 \pm 1.07 \mathrm{mg} / \mathrm{kg}$ and the cyst tissue $9.20 \pm 0.54 \mathrm{mg} / \mathrm{kg}$. Clinostomum tilapiae exhibited the invasive characteristic of trematodes. Season influenced the occurrence of Morphotype1 with higher prevalence in dry (54.01\%) than rainy season months (45.98\%).
\end{abstract}

Keywords: Trematoda; Clinostomum tilapiae; morphotype1; Glycogen; Protein; Seasonal variation.
Received

October 11, 2017

Accepted

December 17, 2017

Released

December 31, 2017

Open Access

Full Text Article

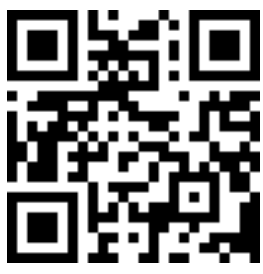

\section{Introduction}

Studies on protein and glycogen contents of Clinostomes metacercariae generally maintain little information. Although an important attempt had been made, it only provided the glycogen content of Clinostomum complanatum (Ramanaiah and Agarwal, 1975). Protein and glycogen contents of other species of Clinostomatids especially those that have been morphologically and molecularly characterized. For instance, lately morphological and molecular $\mid \begin{aligned} & \text { ORCID } \\ & \text { 0000-0001-5868-1142 } \\ & \text { Paul Chinedu Echi } \\ & \end{aligned}$ $\mid \begin{aligned} & \text { ORCID } \\ & \text { 0000-0001-5868-1142 } \\ & \text { Paul Chinedu Echi } \\ & \end{aligned}$ $\mid \begin{aligned} & \text { ORCID } \\ & \text { 0000-0001-5868-1142 } \\ & \text { Paul Chinedu Echi } \\ & \end{aligned}$

Clinostomum characterization of Clinostomum tilapiae Ukoli, 1966 (Digenea: Clinostomidae) and Clinostomum Morphotype1 were done by Caffara et al. (2017) as part of proper identification of clinostomid species based on both molecular and morphological approaches. Therefore, information on their protein and glycogen profiles is important as well as epidemiological information of the later because the epidemiological information of the former had been done. Especially as the basic information on many piscine parasitic species in Africa 
have not been known and therefore data deficient (Echi and Ezenwaji, 2010).

Clinostomids obtain nutrients glucose, and amino acids by both facilitated diffusion and active transport from their intermediate hosts. These parasites do not depend on stored food of their hosts; the nutrients they can obtain from their intermediate hosts are sustainable. Therefore, these metacercariae can remain viable for the longest periods in the hosts. It might last throughout the lives of the host fish due to difficulty in locating their definitive hosts, the piscivorous birds such as Egreta egreta (Higgins, 1979). Besides, such hosts are not ubiquitous in inland waters of West Africa. Though the adults of related species of the piscivorous Egreta egreta, Bubulcus ibis (JX160006) (Echi et al., 2015), are not definitive hosts of clinostomatid parasites, they are ubiquitous around the numerous nature endowed aquatic ecosystems in West Africa. Consequently, absence of known definitive hosts in these West African waters aggravates chances of definitive hosts location.

Due to paucity of information on the protein and glycogen contents of Clinostomum species that occur in West Africa and have been morphologically and molecularly described, I engendered this study to provide them.

\section{Materials and methods}

After the first notice of putative species Clinostomum Morphotype1 in a field survey at Anambra River Basin, Otuocha, Nigeria, sampling port GPS (06 21' 29.211” $\mathrm{N}$ and $06^{\circ}$ 51' 21.911” E), a detailed epidemiological survey has become necessary to update epidemiological information of this new species of Clinostomum. The individual samples of the host $S$. batensoda identified using details in Olaosebikan and Raji (1998) were collected from fishers (May 2016-April 2017) and examined for the presence of Morphotype1 metacercariae. The metacercariae of these Clinostomum species were collected from the host's skin micro-habitats. The parasites were identified using details in Caffara et al. (2017). Infection statistics of Bush et al. (1997) was used for the determination of prevalence. The indistinguishable parasites were sorted as well their cysts and host muscle tissues were excised separately. And they were estimated for both protein and glycogen (Lowry et at., 1951; Kemp and Van Hejnigen, 1954).

\section{Results}

These parasites have only occurred in the skin of these hosts causing large skin grubs (Figure 1).

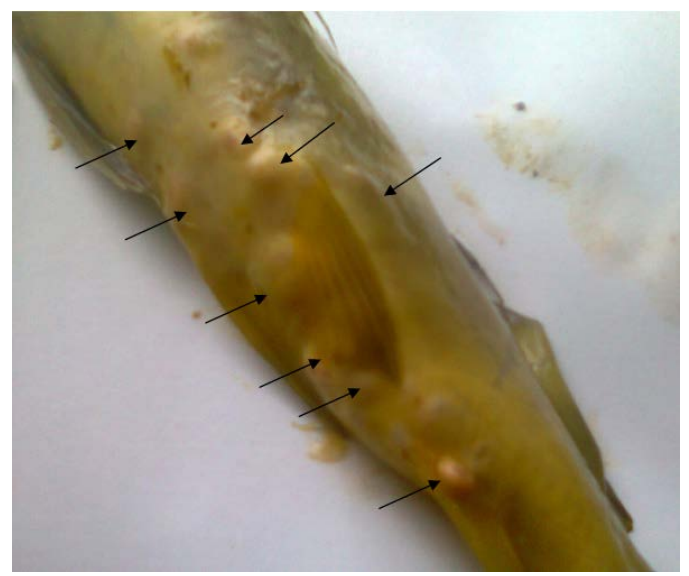

Figure 1. The occurrence of Clinostomum Morphotype1in the skin of $S$. batensoda causing large skin grubs.

When the covering cysts of Morphotype1 are excised, the emerging metacercariae show pied body coloration (yellow and milk colors), stumps of yellow colored pigments one quarter of the body to the posterior end while three quarter and in between the yellow granules there is a typical milk color of Clinostomum metacercariae (Figure 2). The pigments are highly soluble in water and can decolorize the water content where the sample is immersed and pill off on handling; however, when preserved in ethanol, it decolorizes the yellow pigment to characteristic milk color of clinostomid metacercariae. 


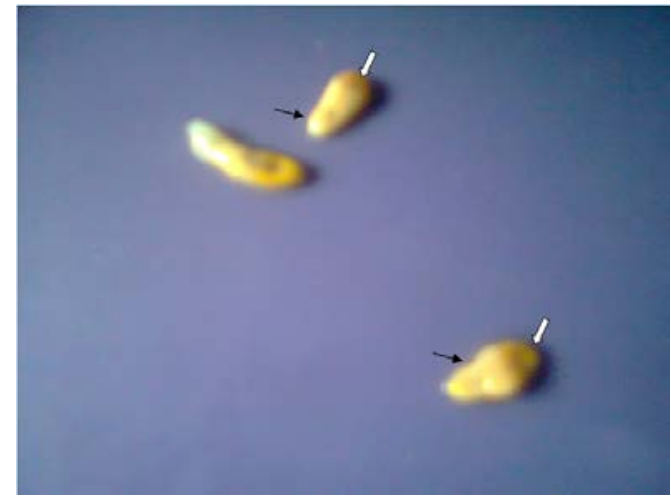

Figure 2. Live metacercariae of Clinostomum Morphotype1 showing two body colorations.

Season influenced the occurrence of Morphotype1 with higher prevalence in dry (54.01\%) than rainy (45.98\%) season months with highest prevalence in January, November and April (10.71\%) and lowest in September (5.36\%).
The cyst membrane and host muscle tissue possessed similar protein contents $\quad 10.10 \pm 0.90 \quad \mathrm{~g} / \mathrm{dL} \quad$ and $11.9 \pm 0.80 \mathrm{~g} / \mathrm{dL}$, respectively, are higher than the protein content of the parasite tissue $7.9 \pm 0.40 \mathrm{~g} / \mathrm{dL}$. Conversely, the host muscle tissue glycogen content $8.25 \pm 1.07 \mathrm{mg} / \mathrm{kg}$ is slightly lower than both the cyst tissue $9.20 \pm 0.54 \mathrm{mg} / \mathrm{kg}$ and Morphotype1 $\quad 9.06 \pm 0.79 \mathrm{mg} / \mathrm{kg}$, respectively. Also, the cyst membrane and host muscle tissue possessed similar protein contents $\quad 10.10 \pm 0.90 \mathrm{~g} / \mathrm{dL} \quad$ and $11.9 \pm 0.80 \mathrm{~g} / \mathrm{dL}$, respectively, that were slightly higher than the protein content of the parasite tissue $9.45 \pm 1.45 \mathrm{~g} / \mathrm{dL}$. However, the glycogen content of the Clinostomum tilapiae $13.10 \pm 0.92 \mathrm{mg} / \mathrm{kg}$ is higher than both host muscle tissue glycogen content $8.25 \pm 1.07 \mathrm{mg} / \mathrm{kg}$ and the cyst tissue $9.20 \pm 0.54 \mathrm{mg} / \mathrm{kg}$.

Table 1. Protein and glycogen profiles of putative species Clinostomum Morphotype1, its cyst, and host muscle tissue.

\begin{tabular}{lccc}
\hline & Encystment tissue & Host muscle tissue & Parasite tissue \\
\hline Protein (g/dL) & $10.10 \pm 0.90$ & $11.9 \pm 0.80$ & $7.9 \pm 0.40$ \\
Glycogen (mg/kg) & $9.20 \pm 0.54$ & $8.25 \pm 1.07$ & $9.06 \pm 0.79$ \\
\hline
\end{tabular}

Table 2. Protein and Glycogen profiles of Clinostomum tilapiae, its cyst, and host muscle tissue.

\begin{tabular}{lccc}
\hline & Encystment tissue & Host muscle tissue & Parasite tissue \\
\hline Protein $(\mathrm{g} / \mathrm{dL})$ & $10.10 \pm 0.90$ & $11.9 \pm 0.80$ & $9.45 \pm 1.45$ \\
Glycogen $(\mathrm{mg} / \mathrm{kg})$ & $9.20 \pm 0.54$ & $8.25 \pm 1.07$ & $13.10 \pm 0.92$ \\
\hline
\end{tabular}

\section{Discussion}

The record of higher prevalence in dry (54.01\%) than rainy (45.98\%) season months has been the trend at Anambra River Basin at Otuocha sampling location. Although under natural conditions, parasitism may vary seasonally, frequent infections of Clinostomum species have been shown to occur during habitat contraction of dry season months when chances of contact between the hosts and the larvae will be higher (ViolanteGonzález et al., 2008; Echi et al., 2014). Similarly, in places where increased human activities are much around water banks and enormous and indiscriminate influx of refuse could support such infection (Echi and Ojebe, 2016).

It is an established fact that many parasites have free living stages (eggs or larvae) which have complimentary behavioral reactions to the ambient environment (Echi and Ezenwaji 2009).

Tropical Africa wet and dry seasons influence general biology of aquatic biodiversity. The parasites therein perhaps evolve mechanism of infestations over years due to the opportunity offered by 
the climatic conditions (Echi and Ezenwaji, 2009).

Occurrence of Clinostomum Morphotype1 only in the skin of these hosts is due to host immune resistance to clinostomid infection unlike clinostomid infection in Cichlids that could affect other host's micro habitats, which had been recorded in previous clinostmid species infection in tropical Africa (Echi and Ojebe, 2016).

Encysting Clinostomum tilapiae
maintain
$13.10 \pm 0.92 \mathrm{mg} / \mathrm{kg}$ levels than the host muscle tissues while Clinostomum Morphotype1 glycogen acquisition is relatively the same with host's glycogen levels. The later therefore maintains good balance in glycogen content relationship with the host. Similarly, Jadhav et al. (2008) reported lower tissue glycogen content in the parasite Davainea shindei $13.20 \mathrm{mg} / \mathrm{kg}$ while the glycogen content in the host intestine was $15.42 \mathrm{mg} / \mathrm{kg}$. Clinostomum tilapiae does not maintain sustainable relationship with the host and this is typical of trematodes. The trematodes maintain more invasive relationships with their hosts (Sonune, 2014).

Parasitic helminth nutrition is a heterotrophic nutrition as they obtain required nutrients from their hosts. A major part of energy source utilized by the parasite is from carbohydrates, the percentage and location of carbohydrates in the host, where the environment is rich for nourishment, normal development and reproduction of the parasite is accounted in the host diet whereas amino acids and fatty acids are involved in the synthesis of macromolecules and egg production. Carbohydrates are very important food component due to its chief energy source in animal body. Different flukes in different parts of both the intermediate and definitive host bodies, utilize the food materials located there. Their metabolism relies on the feeding habits and the rich nourishment available in the infection sites of the hosts. Glucose is also very important energy source for many other parasitic helminthes (Nanware and Bhure, 2011). Essential nutrient component for all metabolic activities in animal tissues relies on glycogen. It is the most important agents for expression of the genetic material and this informs its abundance in all portions of cell structure and function of living cells (Sonune, 2014). Encysted flukes absorb nutrients from their hosts through the membranes of their cysts by active diffusion whereas excysted cysts absorb nutrients directly from their hosts' body fluids. However, excysted clinostomids metacercariae cause more histopathological damages to fish hosts than encysted individuals which is also an explanation of the inability of the host's immunity to cause encystment of these flukes in their host's tissues (Echi et al., 2014).

\section{Conclusion}

The epidemiology of Clinostomum Morphotype1 followed the trend of other studied Clinostomum species in West Africa by occurring more during dry than rainy season months. Also, although, the protein contents of both Clinostomum tilapiae and Clinostomum Morphotype 1 in their hosts show contained parasite - host relationships, the glycogen content of Clinostomum tilapiae exhibits the invasive characteristic of trematodes.

\section{Conflict of interest statement}

Author declares that they have no conflict of interests.

\section{Reference}

Bush, A. O.; Lafferty, K. D.; Lotz, J. M.; Shostak, A. W. Parasitology meets ecology on its own terms: Margolis et al. revisited. The Journal of Parasitology, v. 83, p. 575-583, 1997. https://doi.org/10.2307/3284227

Caffara, M.; Locke, S. A.; Echi, P. C.; Halajian, A.; Benini, D.; Luus-Powell, W. J.; Tavakol, S.; Fioravanti, M. L. A morphological and molecular study of clinostomid metacercariae from African fish with a redescription of Clinostomum tilapiae. Parasitology, v. 144, no. 11, p. 1519-1529, 2017. https://doi.org/10.1017/S0031182017001068 
Echi, P. C.; Ezenwaji, H. M. G. The parasites fauna of characids' (Osteichthyes: Characidae) Anambra River, Nigeria. African Journal of Ecology, $\quad$ v. 48, $\quad$ p. 1-4, 2010. https://doi.org/10.1111/j.1365-2028.2009. 01030.x

Echi, P. C.; Iyaji, F. O.; Ejere, V. C.; Abuh, S. J. Dynamics of synchronized clinostomatids infections in cichlids. Environment Conservation Journal, v. 15, no. 1/2, p. 49-54, 2014. Available from: <http://environcj.in/ uploads/2014/12/Echi,P.C._15(1\&2)_2014_4954.pdf>. Accessed on: Apr. 25, 2017.

Echi, P. C.; Ojebe, M. O. Differences in hostinfection patterns of clinostomatids (Clinostomatidae) in human disturbed aquatic ecosystems against undisturbed lake. Brazilian Journal of Biological Sciences, v. 3, no. 5, p. 97-103, 2016. http://doi.org/10.21472/ bjbs.030508

Echi, P. C.; Suresh, K. U.; George, S.; Ratheesh, R. V.; Ezeonu, I. M.; Ejere, V. C.; Eyo, J. E.; Nwani, C. D. Molecular resolution of some West African Birds using DNA Barcoding. Environment Conservation Journal, v. 16, no. 1/2, p. 87-92, 2015. Available from: <http://www.environcj.in/ uploads/2015/12/87-92.pdf $>$. Accessed on: Apr. 25, 2017.

Higgins, J. C. The role of the tegument of the metacercarial stage of Bucephalus haimeanus (Lacaze-Duthiers, 1854) in the absorption of particulate material and small molecules in solution. Parasitology, v. 78, no. 1, p. 99-106, 1979. https://doi.org/10.1017/S00311820 00048629

Jadhav, B. V.; Singh Shivesh, P.; Bhure, D. B.; Padwal, N. D. Biosystematics studies of Davainea shindei n. sp. (Cestoda: Davainidae) Fuhrmann, 1907 from Gallus gallus domesticus. National Academy Science Letters, v. 31, n. 7/8, p. 245-250, 2008.

Kemp, A.; Van Hejnigen, M. K. A colorimetric micromethod for the determination of glycogen in tissues. Biochemestry Journal, v. 56, p. 646-652, 1954. Available from: $<$ https://www.ncbi.nlm.nih.gov/pmc/articles/PM C1269684/pdf/biochemj01086-0132.pdf>.

Accessed on: Apr. 25, 2017.
Lowry, O. H.; Rosebrough, N. C.; Farr, A. L.; Randall, R. J. Protein measurements with folinphenol reagent. Journal of Biological Chemistry, v. 193, p. 265-275, 1951. Available from:<http://www.jbc.org/content/193/1/265.ful l.pdf $>$. Accessed on: Apr. 25, 2017.

Nanware, S. S.; Bhure, D. B. Studies on glycogen profile of cestodes of Capra hircus. International Multidisciplinary Research Journal, v. 1, no. 10, p. 22-24, 2011. Available from: <https://scienceflora.org/journals/ index.php/imrj/article/view/2688/2666>.

Accessed on: Apr. 25, 2017.

Olaosebikan, B. D.; Raji, A. Field guide to Nigerian freshwater fishes. New Bussa: Federal College of Freshwater Fisheries Technology, 1998.

Ramanaiah, B. V.; Agarwal, S. M. Quantitative studies of glycogen in Clinostomum complanatum (Rud. 1809) and Euclinostomum heterostomum (Rud. 1809) (Clinostomatidae: Trematoda) and a note on the correlation between the total glycogen and the habitat of worms. Indian Journal of Experimental Biology, v. 13, n. 2, p. 221-222, 1975.

Shareef, P. A.; Abidi, S. Incidence and histopathology of encysted progenetic metacercaria of Clinostomum complanatum (Digenea: Clinostomidae) in Channa punctatus and its development in experimental host. Asian Pacific Journal of Tropical Biomedicine, v. 2, no. 6, p. 421-426, 2012. https://doi.org/10.1016/ S2221-1691(12)60068-9

Sonune, M. B. Glycogen content of some Fish Parasites (Cestodes) from West Coast of India. Bioscience Discovery, v. 5, n. 1, p. 32-34, 2014. Available from: $<$ http://biosciencediscovery.com/Vol 5 No 1 Jan 2014/M B Sonune32-34.pdf>. Accessed on: Apr. 25, 2017.

Violante-González, J.; Rojas-Herrera, A.; Aguirre-Macedo, M. L. Seasonal patterns in metazoan parasite community of the "Fat Sleeper" Dormitator latifrons (Pisces: Eleotridae) from Tres Palos Lagoon, Guerrero, Mexico. Revista de Biología Tropical, v. 56, no. 3, p. 419-1427, 2008. Available from: $<$ https://revistas.ucr.ac.cr/index.php/rbt/article/d ownload/5719/5461>. Accessed on: Apr. 25, 2017.

License information: This is an open-access article distributed under the terms of the Creative Commons Attribution License, which permits unrestricted use, distribution, and reproduction in any medium, provided the original work is properly cited. 